\title{
THE DIMINISHING OF THE CONTENT OF TEXTILE DIRECT DYES AND AUXILIARY COMPOUNDS DURING THEIR CATALYTIC OXIDATION
}

\author{
Maria Gonta ${ }^{\mathrm{a}^{*}}$, Gheorghe Duca ${ }^{\mathrm{b}}$, Vera Matveevici ${ }^{\mathrm{a}}$, Larisa Mocanu ${ }^{\mathrm{a}}$ \\ ${ }^{a}$ Moldova State University, 60, Alexei Mateevici str., Chisinau MD-2009, Republic of Moldova \\ ${ }^{b}$ Academy of Sciences of Moldova, 1, Stefan cel Mare blvd., Chisinau MD-2001, Republic of Moldova \\ *e-mail:mvgonta@yahoo.com; phone: (+373 22) 5775 53; fax: (+373 22) 577553
}

\begin{abstract}
Advanced oxidation methods of organic compounds lead to their partial mineralization and increase of the adsorption process efficiency on the surface of oxidized activated carbon. We have studied the oxidation process using model solutions containing mixture of dye direct brown (DB), ethylene glycol (EGL) and sodium lauryl sulfate (SLS) under the action of Fenton reagent, in the presence and absence of UV irradiation or under the action of electric current (in the electrochemical cell). The same studies were performed by replacing the iron (II) ion with titanium dioxide. We have found that the degree of oxidation and mineralization increases by photocatalytic oxidation and decreases the concentration of organic compounds. Due to the oxidation of dye molecules and other auxiliary components, by strong oxidation ability of free $\mathrm{OH}^{*}$ radicals, which evolve to the formation of carbon dioxide, water and low molecular organic compounds (alcohols, ketones, organic acids) are forming. The decrease of the concentration of mixture of organic compounds (for the values of COD-Cr) depends on the nature of catalysts and the presence of electric current. The degree of oxidation is greater in the presence of iron (II) ions than in the presence of titanium dioxide after oxidation of the mixture of organic compounds with hydrogen peroxide in model solutions. This is explained by the fact that UV irradiation increases the concentration of free $\mathrm{OH}^{*}$ radicals as iron ions further decompose hydrogen peroxide, but in the presence of titanium dioxide, the leading band electrons are accepted by free $\mathrm{OH}^{*}$ radicals, converting these radicals to ions, as shown in the mechanism by Garcia J., et al. This leads to a decrease of the concentration of $\mathrm{OH}^{*}$ radicals in model solution and reducing the effect of oxidation, respectively. On the contrary, in the presence of electric current electrons are accepted by the electrode, and the $\mathrm{OH}^{*}$ radicals concentration does not decrease, but increases, and this leads to the enhancement of the oxidation effect and mineralization of organic compounds.
\end{abstract}

Keywords: disperses dye, anionic surfactant, textile wastewater, chemical and electrochemical oxidation, adsorption, $\mathrm{TiO}_{2}, \mathrm{ZrO}_{2}$

\section{Introduction}

The main pollutants in waste waters generated during the technologic coloring of different types of fabrics are diverse classes of dyes as well as auxiliary compounds such as surfactants, polyalcohols, dye fixing agents and others.

Dyes and surfactants are chemically stable compounds that hardly interact with oxidants and cannot be treated by biochemical processes. As a result of discharge into natural water bodies, the disturbance of self-purification processes takes place while the water becomes toxic for water inhabitants. The removal of residues of dyes and surfactants as well as the compliance with sanitary norms is achieved through application of combined methods of treatment that ensure a better oxidation, retention and elimination of pollutants [1]. The methods described in literature [2] refer to adsorption of surfactants by activated charcoal or other synthetic brands of natural adsorbents. The combined processes of treatment of surfactants [1] by means of extraction through flotation and further degradation during the second phase of treatment were investigated as well.

The advanced oxidation methods applied till present rely on degradation of organic compounds into more simple ones or their oxidation with formation of carbon dioxide and water. These pollutants are degraded by $\mathrm{OH} \cdot$ radicals obtained from photochemical decomposition of hydrogen peroxide [3-8]. Due to hydrogen peroxide decomposition the concentration of $\mathrm{OH}$ radicals increases, which respectively increases the rate of oxidation and mineralization of both dyes and surfactants. The rate of oxidation and mineralization is influenced largely by the length and structure of hydrophobic or hydrophilic radicals generated by molecules of surfactant or colorings agents and by the structure of dyes. The increase of the length of hydrocarbon radicals and of the polarity of hydrophilic groups causes the increase of the ratio of oxidation and mineralization. The degree of mineralization of surfactants can reach $60.0-80.0 \%$ [8]. However the removal of surfactants from waste waters from textile industry is impaired by the simultaneous presence of textile dyes and their stabilization by other auxiliary substances that are used in the technological process of coloring of textiles. Application of adsorption methods of removal by activated charcoals is limited due to inefficient removal of only $2.0-4.0 \%$ of surfactants and dyes due to the limited access of associated particles of pollutants to micropores and mesopores [9]. That is why in the first phase of treatment of textile waste waters the coagulation with iron and aluminum salts most often is used. This process consists of iron and aluminum salts dissolution and formation of colloidal particles that are capable to neutralize and sediment surfactants and dyes. The next phases of treatment are applied depending on the chemical oxygen demand, which depends on the remaining pollutants. 
Consequently, the process of treatment and purification of residual waters is a complex task that can be solved only through efficient combined mechanical, chemical, physicochemical and biological methods.

The above mentioned task was addressed through a study of removal of textile coloring mixtures and auxiliary substances through catalytic and photocatalytic oxidation with hydrogen peroxide followed by absorption of residues on activated charcoals depending on the concentration direct dyes, time of catalytic oxidation in the presence of iron (II) ions, titan oxide and zirconium oxide. The mixture was irradiated with UV rays with or without application of electric current.

Experimental laboratory investigations were determined by the increased interest in environmental protection from developing industries. In the Republic of Moldova the problem of efficient purification of wastewaters from textile industry that are discharged in natural water bodies is still not properly solved. It is still necessary to investigate the oxidation of pollutants in systems that simulate the real concentrations of dyes and auxiliary substances. However, literature refers predominantly to treatment of dyes containing methylene blue and methylene orange that have a simple molecular structure and their concentration in solutions is lower than $60 \mathrm{mg} / \mathrm{L}$, and time of treatment is about 4 hours.

\section{Experimental}

The reagents were pure for analysis grade and were acquired from Aldrich Company and other providers. Chemical processes of removal of colorants and auxiliary substances

Chemical and electrochemical methods of advanced oxidation in the presence of catalysts such as Fenton reagent, $\mathrm{TiO}_{2} / \mathrm{H}_{2} \mathrm{O}_{2}, \mathrm{ZrO}_{2} / \mathrm{H}_{2} \mathrm{O}_{2}, \mathrm{UV}$ irradiation at $254,365 \mathrm{~nm}$ were applied.

The investigations were carried out on simulation solutions with 50,100 and $200 \mathrm{mg} / \mathrm{L}$ of colorants, because the range of concentrations of residues in wastewaters can reach $200-250 \mathrm{mg} / \mathrm{L}$.

A mixture of chemical organic compounds consisted of direct textile dye (direct brown (DB)), tensioactive substance (anionic surfactant - sodium lauryl sulfate) and polyalcohol (ethylene glycol). The simulation solutions were chosen according to the content of waste waters. The initial concentration of direct dye varied within the limits from $50 \mathrm{mg} / \mathrm{L}$ till $200 \mathrm{mg} / \mathrm{L}$, while the anionic surfactant constituted $60 \mathrm{mg} / \mathrm{L}$.

The degree of oxidation of textile dyes and mixtures of colorants with surfactants and ethylene glycol were determined according to the COD-Cr method.

The investigation of the catalytic and photocatalytic oxidation followed by absorption of products of oxidation by activated charcoal (KAU-1) was realized according to the method described in the literature [10].

The results of catalytic oxidation in the presence of hydrogen peroxide along with Iron (II) ions and UV radiation have allowed calculation of the degree of oxidation and mineralization (Min., \%) of textile dyes and mixtures investigated according to Eq.(1):

$$
\operatorname{Min}, \%=\frac{C O D_{-} C r_{0}-C O D \_C r_{r e m}}{C O D-C r_{0}} \cdot 100 \%
$$

where $C O D-C r_{r e m}$ represents the residues of organic compounds after one hour of treatment.

A direct textile dye, direct brown (DB), has been used in this study:

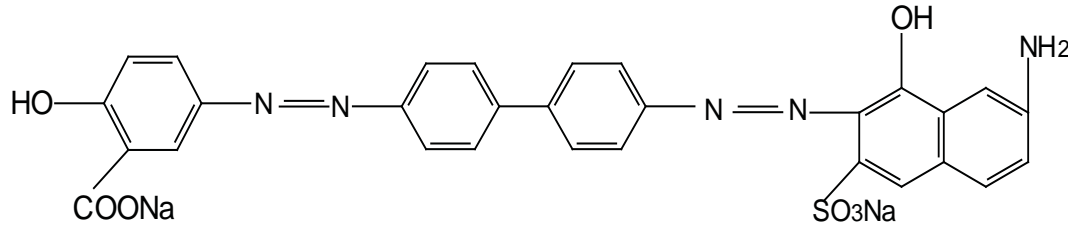

Direct brown (DB)

Besides textile dyes, different classes of surfactants that ameliorate the dying of textile fabrics are present in the waste waters. This work focuses also on the oxidation of anionic surfactant - sodium lauryl sulfate that has the following chemical structure:

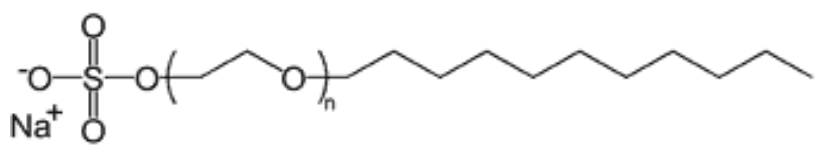

Sodium lauryl sulfate (SLS) 
The polyalcohols are hydroscopic and hydrosoluble compounds and have the role of fixation, dissolving and penetration of dyes into the fabrics. The polyalcohol used in current investigation is ethylene glycol (EGL), which has the following structure:

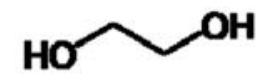

ethylene glycol (EGL)

\section{Methodology}

In a $250 \mathrm{~mL}$ flask a solution of brown direct dye $(0.5 \mathrm{mg} / \mathrm{L})$, anionic surfactant $(20 \mathrm{~g} / \mathrm{L})$ and ethylene glycol $(3 \mathrm{~g} / \mathrm{L})$ were added. The final simulation solution contained $200 \mathrm{mg} / \mathrm{L}$ of colorant, along with $60 \mathrm{mg} / \mathrm{L}$ of surfactant and ethylene glycol. The $\mathrm{pH}$ was adjusted (Consort C $3030 \mathrm{pH}$-meter) with a solution of sulfuric acid during stirring with a WiseStir device. The process of oxidation was investigated at various concentrations of hydrogen peroxide $\left(3 \times 10^{-3}-\right.$ $\left.8 \times 10^{-3} \mathrm{~mol} / \mathrm{L}\right)$ and iron (II) ions $\left(3 \times 10^{-4} \mathrm{~mol} / \mathrm{L}\right)$.

Titanium oxide and zirconium oxide powders were added the system, and UV radiation was generated by a VL-4.LC that assures two wavelengths (254 and $365 \mathrm{~nm}$ ).

The electrochemical treatment was carried out in electrochemical cells with graphite anodes and iron mesh that covers the anode and serves as cathode. The cells were powered by electric generators TEC 14 that assured an intensity of current equal to $0.4 \mathrm{~A}$. In order to launch the electrochemical oxidation $50 \mathrm{~mL}$ of a $0.1 \mathrm{~mol} / \mathrm{L}$ sodium sulfate solution were added to the cell. The solutions were stirred permanently for 10, 20, 40 and 60 minutes on magnetic stirrers. Each consecutive stirring was followed by sampling of $5 \mathrm{~mL}$ of solution, that were transferred into test tubes containing $3 \mathrm{~mL}$ of $\mathrm{K}_{2} \mathrm{Cr}_{2} \mathrm{O}_{7}(0.025 \mathrm{~N})$ each, and addition of $7 \mathrm{~mL}$ of $\mathrm{Ag}_{2} \mathrm{SO}_{4 \text { conc }}$

The test tubes were covered with glass caps and placed in a heating stove (Pol-Eko, Nitech) and stored for $2 \mathrm{~h}$ at $150^{\circ} \mathrm{C}$ in accordance with the method described in [8].

The obtained solutions were tested spectrophotometrically (T60+UV/Vis) at $\lambda=600 \mathrm{~nm}$. The obtained results were used for calculation of the degree of oxidation and mineralization (Min., \%, Equation 1) of textile dyes and mixtures in different conditions.

\section{Results and discussion}

The process of diminishing of the content of mixtures of direct dye and auxiliary compounds on simulation solutions was investigated in the presence of various catalysts. In order to assure the comparison of the results the oxidation of the pure compound was investigated. Figure 1 shows the oxidation of pure surfactant sodium lauryl sulfate for one hour in the presence of Fenton reagent, hydrogen peroxide and titanium dioxide powder. The optimal amounts of iron(II), hydrogen peroxide and titanium oxide were established experimentally. The analysis of results depicted from Figure 1 allow us to conclude that the process of oxidation of anionic surfactant takes place at a higher rate during the first $20 \mathrm{~min}$ of the experiment both in presence of iron ions as well as in the presence of titanium oxide. In both cases the chemical oxygen demand of residues is three times lower than the original concentration of substrate, while the rest of treatment time up to one hour does not affect it significantly.

After one hour of oxidation, in the second phase, the adsorption on activated charcoal was performed. The remaining compounds were again tested according to the COD-Cr procedure $\left(4.0-6.0 \mathrm{mgO}_{2} / \mathrm{L}\right)$ and comply with the standards for allowed emissions in waste waters discharged into natural water bodies. The maximum allowed concentration is $6.0-7.0 \mathrm{mgO}_{2} / \mathrm{L}$.

The results presented in Figure 1 prove that oxidation of the anionic surfactant sodium lauryl sulfate is more intensive in the presence of Fenton reagent than in the presence of titanium oxide.

The mechanism that describes the majority of techniques of advanced oxidation is based on generation of hydroxyl radicals $(\mathrm{OH} \cdot)$ in solution. The hydroxyl radical is a strong oxidation agent that interacts non-selectively with organic compounds. The formation of $\mathrm{OH} \cdot$ radicals occur as a result of irradiation with $\mathrm{UV}\left(\lambda_{\max }=365 \mathrm{~nm}\right)$ due to interactions of valence band holes with molecules of water or $\mathrm{OH}^{-}$ions [10].

$$
\begin{gathered}
\mathrm{TiO}_{2}\left(\mathrm{~h}^{+}\right)+\mathrm{H}_{2} \mathrm{O} \rightarrow \mathrm{TiO}_{2}+\mathrm{OH}^{-}+\mathrm{H}^{+} \\
\mathrm{TiO}_{2}\left(\mathrm{~h}^{+}\right)+\mathrm{OH}^{-} \rightarrow \mathrm{TiO}_{2}+\mathrm{OH}^{-}
\end{gathered}
$$


A decreased efficiency of catalytic oxidation in the case of application of $\mathrm{TiO}_{2}$ powder $(500 \mathrm{mg} / \mathrm{L})$ is caused by the adsorption of surfactants on the surface of the catalysts, thus blocking the active catalytic centers.

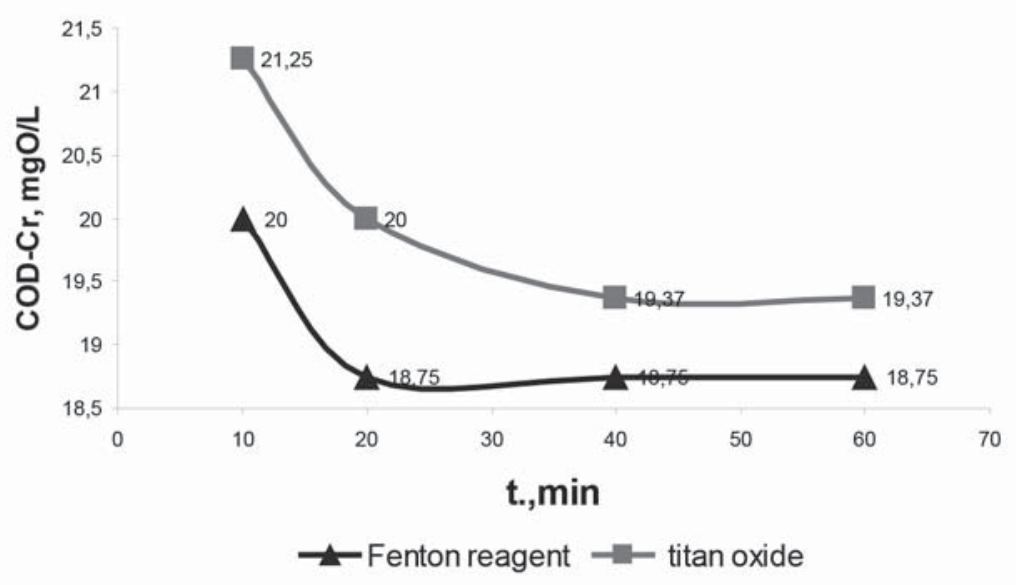

Figure 1. Efficiency of catalytic oxidation in the case of application of $\mathrm{TiO}$, powder and reagent Fenton. [anion.surf. $]=60 \mathrm{mg} / \mathrm{L},\left[\mathrm{H}_{2} \mathrm{O}_{2}\right]=3 \times 10^{-3} \mathrm{~mol} / \mathrm{L},\left[\mathrm{Fe}^{2+}\right]=3 \times 10^{-4} \mathrm{~mol} / \mathrm{L}, \mathrm{pH}=2.0-2.5,\left[\mathrm{TiO}_{2}\right]=500 \mathrm{mg} / \mathrm{L}, \mathrm{pH}=4.0$, $\lambda=365 \mathrm{~nm}, \mathrm{COD}-\mathrm{Cr}_{0}=75 \mathrm{mgO}_{2} / \mathrm{L}$.

The mechanism of photocatalytic degradation in the presence of titanium oxide involves as well formation of superoxide radicals. Due to interactions between $\mathrm{O}_{2}$ and electrons generated by photons in the conduction band the $\mathrm{O}_{2}$ radicals are formed which act as oxidants in reactions with pollutants [10]:

$$
\begin{gathered}
\mathrm{TiO}_{2}(\mathrm{e}-)+\mathrm{O}_{2} \leftrightarrow \mathrm{O}_{2}- \\
\mathrm{O}_{2}-\mathrm{H}^{+} \leftrightarrow \mathrm{HOO} \\
2 \mathrm{HOO} \leftrightarrow \mathrm{O}_{2}+\mathrm{H}_{2} \mathrm{O}_{2}
\end{gathered}
$$

The degree of mineralization of anionic surfactant SLS after $60 \mathrm{~min}$ of oxidation is $18.75 \mathrm{mgO}_{2} / \mathrm{L}$ in case of Fenton reagent and $19.37 \mathrm{mgO}_{2} / \mathrm{L}$ for $\mathrm{TiO}_{2}$. It has been found that during photochemical treatment in the presence of selected catalysts does not achieve the maximum admissible concentration according to COD-Cr. Further, it was studied the adsorption process of remanent compounds from preliminary reactions on active charcoal and results have been reached MAC for COD-Cr.

During the treatment of direct dye the $\mathrm{TiO}_{2}$ and $\mathrm{ZrO}_{2}$ catalysts were used. The aquatic solutions were irradiated at $\lambda \max =365 \mathrm{~nm}$ in the presence of $\mathrm{H}_{2} \mathrm{O}_{2}$ with a concentration of $3 \times 10^{-3} \mathrm{~mol} / \mathrm{L}$. The concentration of the dye in the system consisted $200 \mathrm{mg} / \mathrm{L}$. At concentrations equal to 50 and $100 \mathrm{mg} / \mathrm{L}$ the process of advanced oxidation is complete. However, the concentration of textile dye in wastewaters is significantly higher.

The initial COD-Cr level for the investigated system constituted $220 \mathrm{mgO}_{2} / \mathrm{L}$. During the first $10 \mathrm{~min}$ an intensive process of DB oxidation takes place: in the case of $\mathrm{TiO}_{2}$ the COD-Cr diminishes down to $59.38 \mathrm{mgO}_{2} / \mathrm{L}$, while for $\mathrm{ZrO}_{2}$ a more advanced decrease down to $28.75 \mathrm{mgO}_{2} / \mathrm{L}$ is observed (Figure 2).

In order to determine the efficiency of catalytic oxidation of organic compounds the Equation 1 for assessment of the degree of mineralization was used.

The results presented in Figure 2 show that in the cases of systems with titanium oxide the oxidation of DB occurs at a lower rate in comparison with oxidation catalyzed by zirconium oxide.

The rinsing cycle of fabrics that follows the process of dying requires application of auxiliary components including active surfactant agents and organic solvents. Additionally, optional ingredients such as thick co-emollients and ether oils can be added. The emollient (organic solvent) is constitutes $40 \%$ by weight of the fixation microemulsions. The organic solvents added include aliphatic alcohols that have between 1 and 6 atoms of carbon, or aliphatic polyalcohol compounds such as ethylene glycol, polypropylene- and butylene glycol. 


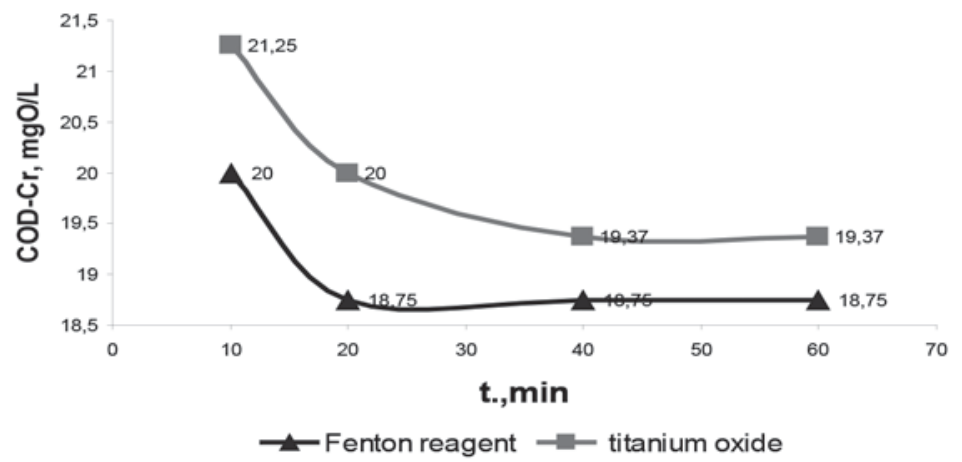

Figure 2. Model systems oxidized titanium oxide and zirconium oxide.

$[\mathrm{DB}]=200 \mathrm{mg} / \mathrm{L},\left[\mathrm{TiO}_{2}\right]$ and $\left[\mathrm{ZrO}_{2}\right]=500 \mathrm{mg} / \mathrm{L}, \mathrm{pH}=4.0,\left[\mathrm{H}_{2} \mathrm{O}_{2}\right]=3 \times 10^{-3} \mathrm{~mol} / \mathrm{L}, \lambda=365 \mathrm{~nm}$.

From the literature reference [3] was found that EGL is oxidized with formation of various organic acids that further on are mineralized down to $\mathrm{CO}_{2}$ and $\mathrm{H}_{2} \mathrm{O}$, although this process is very slow:
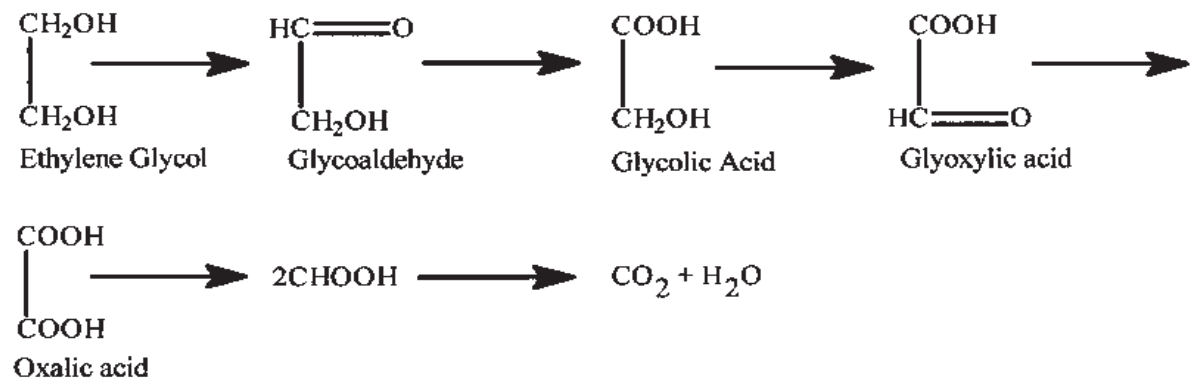

The ethylene glycol in the system was oxidized through irradiation with UV in the presence of titanium oxide and $\mathrm{H}_{2} \mathrm{O}_{2}$. Figure 3 shows that during the first 10 minutes, the oxygen demand decreases by three times (from 66.5 to $20.62 \mathrm{mgO}_{2} / \mathrm{L}$ ). The compounds formed in the process of photocatalytic oxidation still persist in the solution for one hour of treatment. In these conditions EGL cannot be mineralized below the maximum admissible concentration in waste waters that has to be discharged.

The results of the experiment have demonstrated a decrease of the content of organic compounds caused by photocatalytic oxidation of ethylene glycol molecules by $\mathrm{OH}$-forming compounds of more simple structure (alcohols, ketones, organic acids) while a part of it is transformed in carbon dioxide and water which contribute mineralization and decrease of chemical oxygen demand.

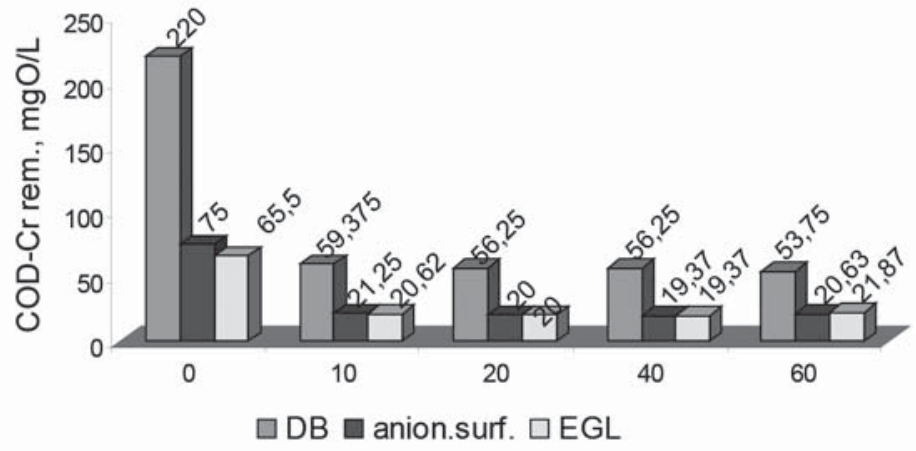

Figure 3. Model system containing dye and auxiliary compounds oxidized titanium oxide. $[\mathrm{DB}]=200 \mathrm{mg} / \mathrm{L},[\mathrm{EGL}]=60 \mathrm{mg} / \mathrm{L}$, [anion.surf. $]=60 \mathrm{mg} / \mathrm{L},\left[\mathrm{H}_{2} \mathrm{O}_{2}\right]=3 \times 10^{-3} \mathrm{~mol} / \mathrm{L}$, $\left[\mathrm{TiO}_{2}\right]=500 \mathrm{mg} / \mathrm{L}, \mathrm{pH}=4.0, \lambda=365 \mathrm{~nm}$. 
In order to bring the content of simulation solutions closer to the state of real waster waters a mixture of similar pollutants including direct dye, EGL and surfactant SLS was investigated. The photocatalytic oxidation was performed for one hour in the presence of $\mathrm{ZrO}_{2}$ with and without addition of $\mathrm{H}_{2} \mathrm{O}_{2}$. The experimental results are presented in Figure 4.

The results of the experimental investigations have proved that addition of $\mathrm{H}_{2} \mathrm{O}_{2}$ takes place at a lower rate in comparison with the mixtures where was not added. The mechanism of formation of free radicals during photocatalytic oxidation when zirconium oxide was used without addition of $\mathrm{H}_{2} \mathrm{O}_{2}$ can be represented as follows:

$$
\begin{gathered}
\mathrm{ZrO}_{2}+\mathrm{hv} \rightarrow \mathrm{ZrO}_{2}+\mathrm{e}_{\mathrm{cb}}{ }^{-}+\mathrm{ZrO}_{2}+\mathrm{h}^{+}{ }_{\mathrm{vb}} \\
\mathrm{ZrO}_{2}+\mathrm{e}_{\mathrm{cb}}{ }^{-}+\mathrm{O}_{2} \rightarrow \mathrm{ZrO}_{2}+\mathrm{O}_{2}{ }^{*-} \\
\mathrm{O}_{2}{ }^{*-}+\mathrm{H}^{+} \rightarrow \mathrm{HO}_{2}^{*} \\
\mathrm{HO}_{2}{ }^{*}+\mathrm{P} \rightarrow \text { products of oxidation }
\end{gathered}
$$

The mechanism of the process that do not use $\mathrm{H}_{2} \mathrm{O}_{2}$ can be explained by the transfer of electrons from the valence band of zirconium to the conduction band and their gain by oxygen molecules and not by hydrogen peroxide that are responsible for generation of $\mathrm{OH} \cdot$ radicals. Therefore, in the systems that do not contain $\mathrm{H}_{2} \mathrm{O}_{2}$ instead of $\mathrm{OH} \cdot$ radical formation the formation of $\mathrm{HO}_{2}$-radicals takes place, while in the systems where the $\mathrm{H}_{2} \mathrm{O}_{2}$ was added the formation of $\mathrm{OH} \cdot$ occurs under the influence of UV rays.

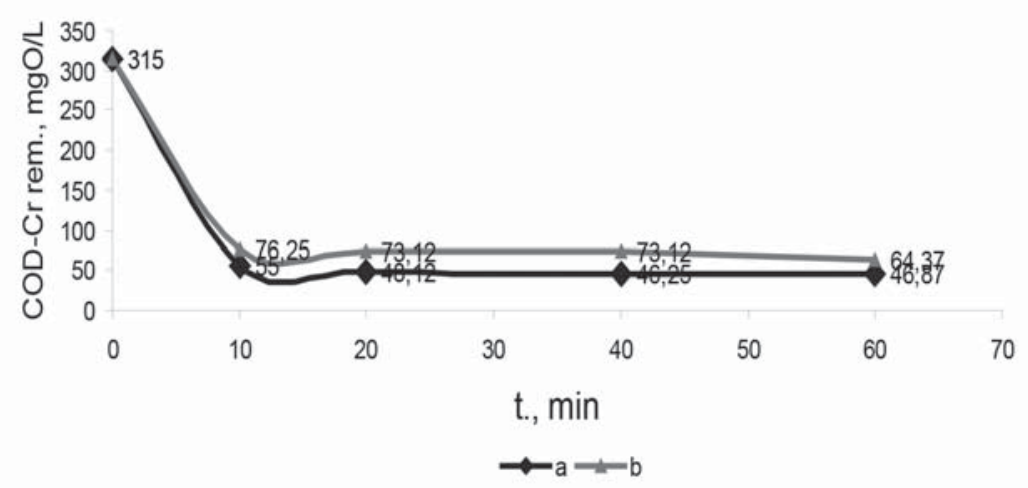

Figure 4. Photocatalytic oxidation in the presence of $\mathrm{ZrO}_{2}$ with and without the addition of $\mathrm{H}_{2} \mathrm{O}_{2}$. a - without $\mathrm{H}_{2} \mathrm{O}_{2}$, b- with $\mathrm{H}_{2} \mathrm{O}_{2},[\mathrm{DB}]=\mathbf{2 0 0} \mathrm{mg} / \mathrm{L}$, [EGL $]=60 \mathrm{mg} / \mathrm{L}$, [anion. surf. $]=60 \mathrm{mg} / \mathrm{L}$ $\left[\mathrm{ZrO}_{2}\right]=500 \mathrm{mg} / \mathrm{L}, \mathrm{pH}=4.0,\left[\mathrm{H}_{2} \mathrm{O}_{2}\right]=3 \times 10^{-3} \mathrm{~mol} / \mathrm{L}, \lambda=365 \mathrm{~nm}$.

In the absence of gaining oxidants, the electron from the conduction band can be gained by $\mathrm{OH}$-radicals which leads to diminishing of the content of oxidative panicles in solution:

$$
\begin{gathered}
\mathrm{ZrO}_{2}+\mathrm{h}_{\mathrm{vb}}^{+}+\mathrm{H}_{2} \mathrm{O}_{\mathrm{s}} \rightarrow \mathrm{ZrO}_{2}+\mathrm{OH}_{\mathrm{s}}^{-}+\mathrm{H}^{+} \\
\mathrm{ZrO}_{2}+\mathrm{h}_{\mathrm{vb}}^{+}+\mathrm{OH}_{\mathrm{s}}^{-} \rightarrow \mathrm{ZrO}_{2}+\mathrm{OH}^{*} \\
\mathrm{ZrO}_{2}\left(\mathrm{e}_{\mathrm{cb}}^{-}\right)+\mathrm{HO} \rightarrow \mathrm{OH}^{-}+\mathrm{ZrO}_{2}
\end{gathered}
$$

It became known that the absence of hydrogen peroxide the rate of oxidation and mineralization are increased both in the presence of zirconium oxide and titanium oxide. In order to diminish the negative effect of electrons from the conduction band additional oxygen is pumped into the water.

The effect of diminishing of the content of organic compounds in mixtures during oxidation in the presence of hydrogen peroxide is influenced by the amount of direct dyes in the mixture, the nature of catalyst and presence of UV radiation. The experimental investigations summarized in Table 1 show that oxidation effect and rate of mineralization is affected by the nature of catalyst.

The remaining content of degradable compounds decreases for the duration of one hour as follows: utilization of Fenton reagent decreases the level of COD-Cr from $300 \mathrm{mgO}_{2} / \mathrm{L}$ to $96.87 \mathrm{mgO}_{2} / \mathrm{L}$, while the rate of oxidation and mineralization constitutes $67.71 \mathrm{mgO}_{2} / \mathrm{L}$. 
During utilization of Fenton reagent the COD-Cr decreases from $300 \mathrm{mg} / \mathrm{L}$ to $35.0 \mathrm{mg} / \mathrm{L}$, and the rate of oxidation and mineralization constitutes $88.22 \mathrm{mgO}_{2} / \mathrm{L}$.

The mineralization and oxidation effect is affected also by the presence of UV rays, since in this case the concentration of $\mathrm{OH} \cdot$ radicals produced from decomposition of hydrogen peroxide is increasing in accordance with the following mechanism:

$$
\begin{gathered}
\mathrm{H}_{2} \mathrm{O}_{2}+\mathrm{hv} \rightarrow 2 \mathrm{OH}^{*} \\
\mathrm{Fe}^{2+}+\mathrm{H}_{2} \mathrm{O}_{2} \rightarrow \mathrm{Fe}^{3}+\mathrm{OH}^{*}+\mathrm{OH}^{-}
\end{gathered}
$$

In this case the concentration of $\mathrm{OH}$ is increased and respectively is increased the rate of oxidation and mineralization of dyes and surfactants. According to estimations based on measuring of COD-Cr and the rate of oxidation, the utilization of $\mathrm{TiO}_{2}+\mathrm{UV}$ catalyst is less effective than application of Fenton reagent. In the presence of hydrogen peroxide the process takes place with formation of an additional amount of $\mathrm{OH} \cdot \mathrm{radicals}$ that is influenced by the content of titanium oxide, wavelength of UV radiation and time of irradiation:

$$
\mathrm{TiO}_{2}\left(\mathrm{e}_{\mathrm{cb}}^{-}\right)+\mathrm{H}_{2} \mathrm{O}_{2} \rightarrow \mathrm{HO}+\mathrm{OH}^{-}
$$

When acceptor oxidants are not present the electrons from the conduction band can be gained by $\mathrm{OH} \cdot$ which leads to diminishing of their content in solution:

$$
\mathrm{TiO}_{2}\left(\mathrm{e}_{\mathrm{cb}}^{-}\right)+\mathrm{HO} \rightarrow \mathrm{OH}^{-}
$$

Table 1

The diminishing of the content of dye and auxiliary compounds at treatment in the presence of various catalysis. $[\mathrm{DB}]=\mathbf{2 0 0} \mathrm{mg} / \mathrm{L}$, $[$ anion.surf. $]=60 \mathrm{mg} / \mathrm{L},\left[\mathrm{H}_{2} \mathrm{O}_{2}\right]=3 \times 10^{-3} \mathrm{~mol} / \mathrm{L},\left[\mathrm{Fe}^{2+}\right]=3 \times 10^{-4} \mathrm{~mol} / \mathrm{L}, \mathrm{pH}=\mathbf{2 . 0 - 2 . 5}$, $\left[\mathrm{TiO}_{2}\right]=500 \mathrm{mg} / \mathrm{L}, \mathrm{pH}=3.5-4.0, \lambda=365 \mathrm{~nm}$.

\begin{tabular}{|l|c|c|c|c|c|c|}
\hline \multirow{2}{*}{ t, min. } & \multicolumn{2}{|c|}{ Fenton } & \multicolumn{2}{c|}{ Fenton $+\mathrm{UV}$} & \multicolumn{2}{c|}{$\mathrm{TiO}_{2}+\mathrm{UV}$} \\
\cline { 2 - 7 } & $\mathrm{COD}-\mathrm{Cr}, \mathrm{mgO}_{2} / \mathrm{L}$ & Min., $\%$ & $\mathrm{COD}-\mathrm{Cr}, \mathrm{mgO}_{2} / \mathrm{L}$ & $\mathrm{Min} ., \%$ & $\mathrm{COD}-\mathrm{Cr}, \mathrm{mgO}_{2} / \mathrm{L}$ & $\mathrm{Min} ., \%$ \\
\hline \multicolumn{7}{|c|}{ Chemical treatment, COD-Cr ${ }_{0}$ mixt. $=315 \mathrm{mgO}_{2} / \mathrm{L}$} \\
\hline 10 & 104 & 65.33 & 45.00 & 85.00 & 60.00 & 80.00 \\
\hline 20 & 98.75 & 67.08 & 42.50 & 85.83 & 50.00 & 83.33 \\
\hline 40 & 97.5 & 67.50 & 38.75 & 87.08 & 36.25 & 87.92 \\
\hline 60 & 96.87 & 67.71 & 35.00 & 88.33 & 36.25 & 87.92 \\
\hline AC & 5.62 & 98.13 & 5.00 & 98.33 & 5.62 & 98.13 \\
\hline
\end{tabular}

In all the cases the COD-Cr exceeds the admissible concentration requested for waste waters. Taking this into account, the process of adsorption of residues of oxidation on active charcoal (AC) with a concentration of $500 \mathrm{mg} / \mathrm{L}$ was investigated. Following the adsorption (Table 1) the COD-Cr for all the samples of oxidation has decrease to $5 \mathrm{mgO}_{2} / \mathrm{L}$, while the rate of oxidation has risen by $98.0 \%$. Thus, the conditions for a complete treatment were optimized that would assure the compliance with sanitary norms of divers waste waters.

Similarly the electrochemical oxidation of organic compounds in simulation solutions containing mixtures of direct textile dye along with anionic surfactant SLS and ethylene glycol was investigated and proved according to COD-Cr. The experiment results show that organic components content decreases as a result of electrochemical oxidation in the presence of hydrogen peroxide catalyzed with Fenton reagent, titanium oxide or photo-Fenton at irradiation with ultraviolet rays (UV) at the optimal wavelength of $365 \mathrm{~nm}$. The results obtained are presented in Figure 6 and Table 2.

Table 2

Diminishing of the concentration of dye and auxiliary compounds with different catalysts. $[\mathrm{DB}]=200 \mathrm{mg} / \mathrm{L}$, [anion. surf. $]=60 \mathrm{mg} / \mathrm{L},\left[\mathrm{H}_{2} \mathrm{O}_{2}\right]=3 \times 10^{-3} \mathrm{~mol} / \mathrm{L},\left[\mathrm{Fe}^{2+}\right]=3 \times 10^{-4} \mathrm{~mol} / \mathrm{L},\left[\mathrm{TiO}_{2}\right]=500 \mathrm{mg} / \mathrm{L}, \lambda=365 \mathrm{~nm}$.

\begin{tabular}{|l|c|c|c|c|c|c|}
\hline \multirow{2}{*}{ t, min. } & \multicolumn{2}{|c|}{ Fenton, $\mathrm{pH}=2.0-2.5$} & \multicolumn{2}{c|}{ Fenton $+\mathrm{UV}, \mathrm{pH}=2.0-2.5$} & \multicolumn{2}{c|}{$\mathrm{TiO}_{2}+\mathrm{UV}, \mathrm{pH}=3.5-4.0$} \\
\cline { 2 - 7 } & $\mathrm{COD}-\mathrm{Cr}, \mathrm{mgO}_{2} / \mathrm{L}$ & Min., $\%$ & COD-Cr, $\mathrm{mgO}_{2} / \mathrm{L}$ & $\mathrm{Min} ., \%$ & $\mathrm{COD}-\mathrm{Cr}, \mathrm{mgO}_{2} / \mathrm{L}$ & $\mathrm{Min} ., \%$ \\
\hline \multicolumn{7}{|c|}{ Electrochemical treatment, COD-Cr ${ }_{0}$ mixt. $=315 \mathrm{mgO}_{2} / \mathrm{L}$} \\
\hline 10 & 47.5 & 84.17 & 32.5 & 89.17 & 63.75 & 78.75 \\
\hline 20 & 28.75 & 90.42 & 31.25 & 89.58 & 50.00 & 83.33 \\
\hline 40 & 24.37 & 91.88 & 30.63 & 89.79 & 41.87 & 86.04 \\
\hline 60 & 11.87 & 96.04 & 23.75 & 92.08 & 40.62 & 86.46 \\
\hline $\mathrm{AC}$ & 0.62 & 99.79 & 5.63 & 98.12 & 28.75 & 90.42 \\
\hline
\end{tabular}


From Figure 6 it is observed that the process of catalytic oxidation with hydrogen peroxide through electrochemical method in the presence of titanium dioxide at higher concentrations of direct dye takes place with a lower rate in comparison with Fenton and photo-Fenton methods. After the chemical and electrochemical treatment, during the second phase the active charcoal was used for adsorption in order to reach the maximum admissible concentration for certain mixtures.

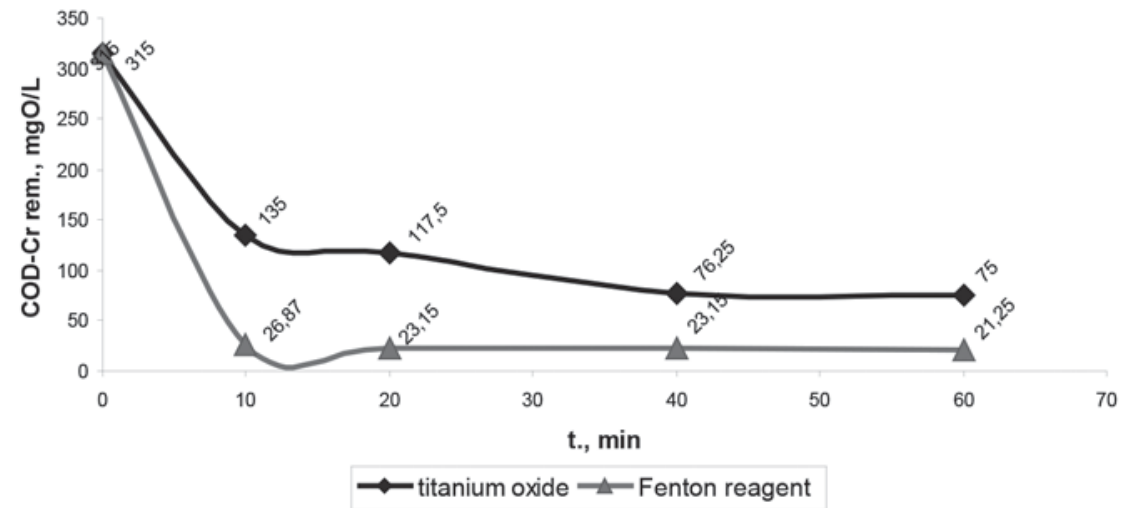

Figure 6. Electrochemical treatment $(0.4 \mathrm{~A}),[\mathrm{DB}]=200 \mathrm{mg} / \mathrm{L}$, [EGL] $=60 \mathrm{mg} / \mathrm{L}$, [anion. surf.] $=60 \mathrm{mg} / \mathrm{L}$, $\left[\mathrm{TiO}_{2}\right]=500 \mathrm{mg} / \mathrm{L}, \mathrm{pH}=4.0,\left[\mathrm{Fe}^{2+}\right]=3 \times 10^{-4} \mathrm{~mol} / \mathrm{L}, \mathrm{pH}=2.0-2.5,\left[\mathrm{H}_{2} \mathrm{O}_{2}\right]=8 \times 10^{-3} \mathrm{~mol} / \mathrm{L}, \lambda=365 \mathrm{~nm}$.

\section{Conclusions}

The mixture of direct dye DB and anionic surfactant SLS and EGL is oxidized more efficiently through Fenton and photo-Fenton methods in comparison with application of titanium oxide as catalyst.

It was identified that the oxidation for one hour of a mixture of DB, ethylene glycol and anionic surfactant SLS in model solutions using the photo-Fenton and electrochemical methods, the degree of oxidation and mineralization can reach $91.0-95.0 \%$.

It has been proved that direct dye DB, surfactant SLS and ethylene glycol can be removed from waste water through combined methods of photocatalytic oxidation with hydrogen peroxide, electrochemical treatment and adsorption of degraded compounds on active charcoal.

\section{Acknowledgements}

It is acknowledged the Government of Republic of Moldova and Academy of Sciences of Moldova for financial support.

\section{References}

1. Alcantara, M. T.; Gomez, J.; Pazos, M.; Sanroman, M. A. Combined treatment of PAHs contaminated soils using the sequense extrasionn with surfactant- electrochemical degradation. Chemosphere, 2008, 70, pp. 1438-1444.

2. Bouras, O.; Bollinger, J.; Baudu, M.; Khalay, H. Adsorption of diuron and its degradation products from aqueous solution by surfactant -modified pillared clays. Applied Clay Science. 2007, 37, pp. 240-250.

3. Dietrick McGinnis, B.; Dean Adams, V. Degradation of ethylene glycol using Fenton's reagent and UV. Chemosphere, 2001, 45, pp. 101-108.

4. Fabiana, M.; Paschoal, M.; Marc. A.; Anderson, A.; Valnice, M.; Zanoni, B. Fotoelectocatalytic oxidation of anoinic surfactant used in leather industry on nanoporous $\mathrm{Ti} / \mathrm{TiO}_{2}$ electrodes. Journal of the Brazilian Chemical Society. 2008, 19(4), pp. 603-810.

5. Hidaka, H.; Ajisaka, K.; Harikoshi, S.; Oyama, T.; Takauchi, K. Comparative assessment of the efficiency of $\mathrm{TiO}_{2} / \mathrm{OTE}$ thin film electrodes fabricated by three deposition methods. Photoelectrochemical degradation of the DBS anionic surfactant. Journal of Photochemistry and Photobiology, A. Chemistry. 2001, 138, pp. 185-192.

6. Ma, C.W.; Chu, W. Photodegradation mechanism and rate improvement of chlorinated aromatic dye in non-ionic surfactant solutions. Water Resources. 2001, 35(10), pp. 2453-2459.

7. Matveevici, V.; Duca, Gh.; Gonta, M.; Isac, T.; Mocanu, L. Studying the process of reducing the concentration of active dyes in model solutions by applying physico - chemical methods. Studia Universitatis, series "Natural Sciences", 2010. 31(1), pp. 162 - 172 (in Romanian).

8. Michitaka, O.; Hirofurni, S.; Hiroyuki, F.; Koichi, E. Intramolecularly selective decomposition of surfactant molecules on photocatalytic oxidative degradation over $\mathrm{TiO}_{2}$ photocatalyst. Journal of Molecular Catalysis A. Chemical, 2000, 155, pp. 122-129.

9. Lupascu, T. Activated carbons from vegetal raw materials; Chisinau: Stiinta, 2004, 224 p. (in Romanian).

10. Lu, P.; Chien, C.-W.; Chen, T.-S.; Chern, Jia-Ming. Azo dye degradation kinetics in $\mathrm{TiO}_{2}$ film-coated photoreactor. Chemical Engineering Journal, 2010, 163, pp. 28-34. 